\title{
Salt Based Dry Fish Processing and Marketing by Fishers of Minneriya Reservoir in Sri Lanka
}

\author{
R.M.N.S. Sugathapala*, T.V. Suntharabarathy ${ }^{1}$ and U. Edirisinghe ${ }^{2}$ \\ Postgraduate Institute of Agriculture \\ University of Peradeniya \\ Sri Lanka
}

\begin{abstract}
Fish represent a major source of animal protein in the Sri Lankan diet. However, it is more susceptible to spoilage than other animal food. The objectives of this study were to determine the scientific basis of the preparation and the selection of freshwater fish species for dry fish production and to analyze the profitability of dry fish marketing in Minneriya. Data were collected by on-site observations and interviews with randomly selected five dry fish sellers, twenty involved fishermen and fifty consumers using a semistructured questionnaire. Salting and sun drying are the main fish preservation methods in this area and consumer preference for dry fish is significantly high. For processing, small $(6.875-8.750 \mathrm{~cm})$ and damaged fish are collected, split ventrally, and the gut and skin are removed completely. Fish are then washed thoroughly and salted at a ratio of 1:3 (salt:fish), mixed well and packed into plastic buckets (20L) and kept for 2-3 day. The salted fish are then spread on large stones and sun dried. Puntius filamentosus, Oreochromis mossambicus,

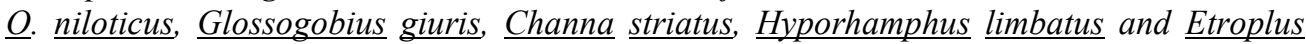
suratensis are used for dry fish preparation. Carcass recovery of fish was 33.3\%. Dry fish was sold to grocery stores at Minneriya and to the Dambulla market, with a profit of Rs. $255 /$ - per $\mathrm{kg}$ and a market margin of $72.9 \%$. The findings indicate that dry fish marketing is a profitable, low cost option for small-scale producers in Minneriya. The quality of the final product could be improved by educating fishermen to use clean water and quality salt for processing and by introducing simple equipment such as solar or artificial dryers for drying, thus preventing contamination and dependence on weather conditions.
\end{abstract}

Keywords: Carcass recovery, marketing, salting, sun drying

\section{INTRODUCTION}

Fish products represent the major source of animal protein in the Sri Lankan diet. Fish, however, is more susceptible to spoilage than certain other animal protein foods (Cutting, 1996). Fish is perishable and must be processed within a few hours of being caught, because no form of processing or preservation can improve the quality of spoiled fish (Lliyasu et al., 2011). As a part of the natural process by which organic matter is broken down and returned to the nitrogen cycle, fish flesh is rapidly invaded, digested and spoiled by the microorganisms which are abundant on the skin, gills and in the intestine. Ferments also contribute to the dissolution and oxidation and are an additional process of deterioration (Cutting,

\footnotetext{
Department of Biological Sciences, Faculty of Applied Sciences, Rajarata University of Sri Lanka, Mihintale, Sri Lanka

2 Department of Animal Science, Faculty of Agriculture, University of Peradeniya, Peradeniya, Sri Lanka

* Author for correspondence: nirmalasajeewani@yahoo.com
} 
1996). Fish is a low acid food and is therefore, very susceptible to the growth of food poisoning bacteria. As a result, methods of preservation to counteract these processes have become essential to the utilization of fish as food in the past (Cutting, 1996).

Simple drying in the sun would have been one of the oldest methods of preservation applied for fish. But it takes comparatively long time. In order to prevent this, the method of salt curing is employed (Govindan, 1985). Dry fish preparation should open up new possibilities to reduce physical post harvest losses and also add value to harvest.

The objectives of this study were to studies the scientific basis of the adopted methodology; details of freshwater fish species used for dry fish preparation and analyze the profitability of dry fish marketing in Minneriya, an area located in the North Central Province of Sri Lanka.

\section{MATERIALS AND METHODS}

\section{Study area}

Minneriya reservoir is a shallow, lowland irrigation reservoir located at approximately $20 \mathrm{~km}$ north-west of Polonnaruwa, $96 \mathrm{~m}$ above mean sea level in the north central dry zone $\left(6^{0}\right.$ $20^{\prime} \mathrm{N}$ : $80^{\circ} 53^{\prime} \mathrm{E}$ ) of Sri Lanka. The reservoir is fed by waters from the 'Amban ganga' and 'Mahaweli river' (Silva \& Gamlath, 2000). The area around Minneriya reservoir was selected as the study site and data were collected by on-site observations and interviews with randomly selected dry fish sellers (5), fishermen (20) and consumers (50) using a pre-tested semi-structured questionnaire.

The method used for dry fish preparation was studied by on-site observations in different areas around the Minneriya reservoir. Marketing data were collected from randomly selected five fish sellers and from twenty fishermen using a pre-tested semi structured questionnaire. The details of consumers were collected from dry fish sellers in randomly selected areas using a semi-structured questionnaire.

Fish samples were taken for species identification during on-site observations at the village houses, where the preparation is done.

\section{Data analysis}

Profit $(\mathrm{Rs} . / \mathrm{kg})(\pi)=$ Total revenue $(\mathrm{TR})-$ Total variable cost $(\mathrm{TVC})$

Where, $\mathrm{TR}=\mathrm{p} \times \mathrm{y}$ where, $\mathrm{p}=$ price per $\mathrm{kg}$ of dry fish $(\mathrm{Rs}) ; \mathrm{y}=$ out put $(\mathrm{kg})$

TVC $=$ Total variable costs (Rs), which include cost of fish, transport cost, processing cost, labour cost, packaging cost... etc (Lliyasu et al., 2011).

Market Margin $(\mathrm{MM})=($ Retail price - Farm gate price $)$

$\%$ Carcass recovery of fish $=($ Weight of fish after drying $/$ Fresh weight of fish $) \times 100$

$\%$ Consumer preference for dry fish $=($ Number of consumers preferred dry fish $/$ Number of consumers interviewed) $\mathrm{x} 100$ ).

Profit and market margin analysis was used to determine the profitability of dry fish marketing in Minneriya area. 


\section{RESULTS AND DISCUSSION}

Fish is an extremely perishable food. For example, most fish become inedible within $12 \mathrm{~h}$ at tropical temperatures. Spoilage begins as soon as fish dies, and processing should therefore, be done quickly to prevent the growth of spoilage bacteria.

\section{Method used for dry fish preparation}

Salting with sun drying is the main fish preservation method in this area. Small fish (6.875$8.75 \mathrm{~cm}$ ) and damaged fish are collected, for processing. They are split ventrally (Fig. 1), and the gut and skin are removed completely (Fig. 2). Fish are then washed thoroughly. Then salt is added in 1:3 (salt:fish) by wet weight basis (Fig. 3) and mixed well (Fig. 4). Salted fish are next packed in plastic buckets (20 L) (Fig. 5) and kept for 2-3 days. The salted fish were then spread on large stones and sun dried (Fig. 6).

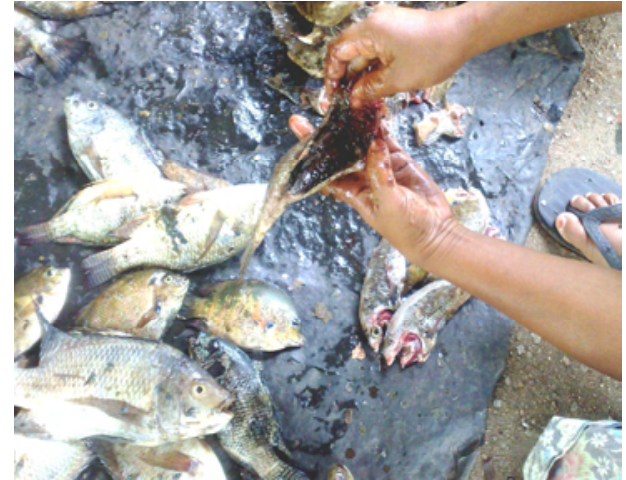

Fig. 1. Fish split ventrally

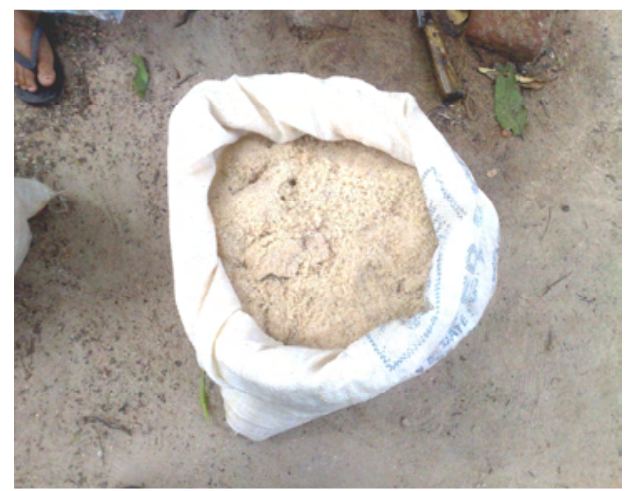

Fig. 3. Salt used for processing

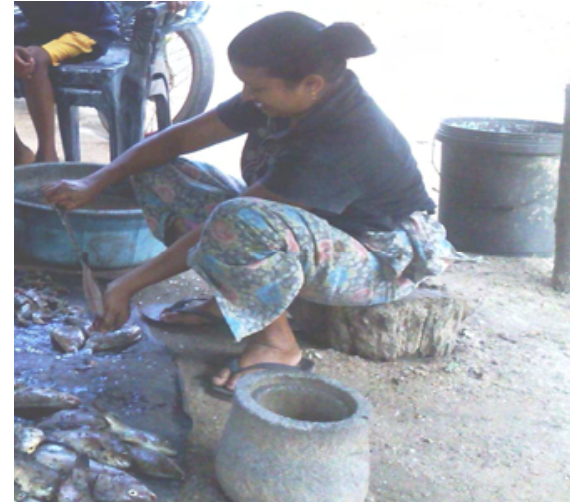

Fig. 2. Gut and skin removed completely

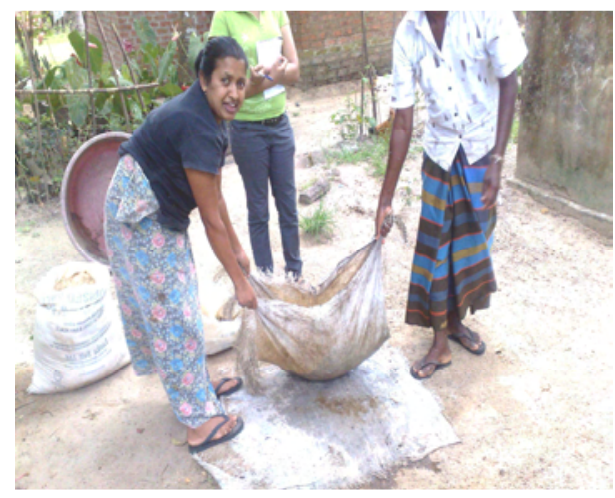

Fig. 4. Mixing with salt 


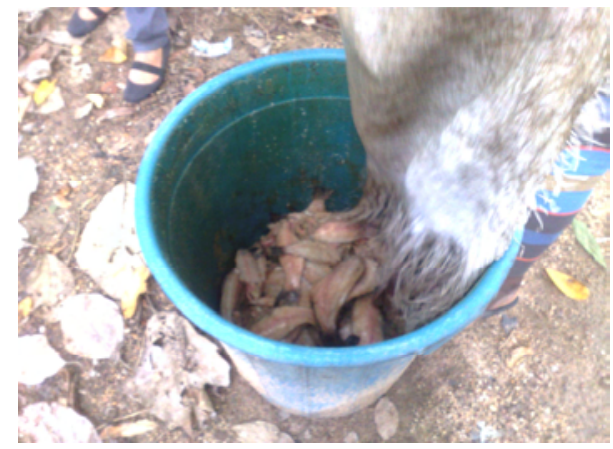

Fig. 5. Plastic buckets packed with salted fish

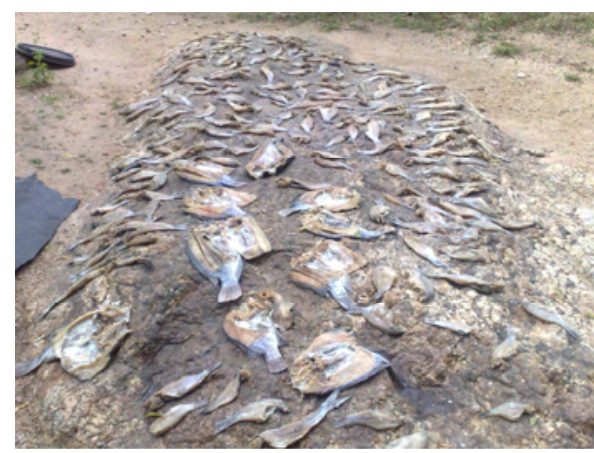

Fig. 6. Sun drying

The scientific principle behind drying is the preservative action taking place due to removal of water from the fish cells and lowering their moisture content to low levels so as to prevent the growing of microorganisms like bacteria and fungi, which are mostly responsible for bringing about spoilage reactions. These organisms require a maximum of over $11 \%$ level of moisture in the material, below which they cannot live and multiply. Drying brings the moisture content of the food material below this level. But sun drying takes comparatively longer time to reduce moisture to the critical levels. This time delay allows microbes and enzymes start reaction causing considerable spoilage of the muscle (Govindan, 1985).

In order to prevent the microbial activation during processing, salt-based sun-drying is employed. In salt based drying, fish are subjected to a preliminary treatment with salt. During salting two processes take place simultaneously. Water moves from the fish into the solution outside and a little quantity of salt moves from the outside into the cells of the fish. Most food poisoning bacteria cannot live in salty conditions. Salt is applied in the ratio of 1:3 and salt draws out the water from the fish cells and forms 'self brine'. Fish are kept 2-3 days in plastic buckets, by which time fish flesh and residual fluid get saturated with salt. Fish also shrink considerably. Salting is followed by sun drying, where heat of the sun and movement of air remove the moisture and provide a safe final product. Carcass recovery of fish was $33.3 \%$.

Freshwater fish species used for dry fish preparation were Puntius filamentosus, Oreochromis mossambicus, O. niloticus, Glossogobius giuris, Channa striatus, Hyporhamphus limbatus and Etroplus suratensis (Table 1).

Table 1. Fresh water fish species used for dry fish preparation

\begin{tabular}{lll}
\hline Family & \multicolumn{1}{c}{$\begin{array}{c}\text { Common name } \\
\text { (English/sinhala) }\end{array}$} & \multicolumn{1}{c}{ Scientific name } \\
\hline Cyprinidae & Filamented barb/ Pethiya & Puntius filamentosus \\
Cichlidae & Pearl spot/ Koraliya & Etroplus suratensis \\
& Tilapia/ Mossambic tilapiya & Oreochromis mossambicus \\
& Nile Tilapia/ Batta & Oreochromis niloticus \\
Gobiidae & Bar eyed goby/ Weligouwa & Glossogobius giuris \\
Channidae & Murrel/Loola & Channa striatus \\
Hemiramphidae & Halfbeak/ Morella & Hyporhamphus limbatus \\
\hline
\end{tabular}


Table 2. Profit and market margin analysis of dried fish

\begin{tabular}{lr}
\hline Function & Value \\
\hline Price per kg of fish (Rs) & 350.00 \\
Output (kg) & 45.00 \\
Cost per kg fish (Rs) & 70.00 \\
Input (kg) (Carcass recovery 3:1) & 135.00 \\
Transport cost (Rs) & 100.00 \\
Labour cost (Rs) & 500.00 \\
Packing cost (Rs) & 100.00 \\
Total variable cost (TVC)(Rs) & 10150.00 \\
Gross profit ( $\pi$ ) (Rs) & 5600.00 \\
Farm gate price (Rs/kg) & 350.00 \\
Retail price (Rs/kg) & 400.00 \\
Market margin $(\mathrm{Rs})$ & 50.00 \\
\hline
\end{tabular}

Market for dryfish is mostly in Minneriya and Dambulla. The fish is sold, with a profit of Rs. 5600.00 and a market margin of $50.00 \mathrm{Rs} / \mathrm{kg}$ (Table 2). Since dry fish was made out of cheaply available, unmarketable fish (in fresh form), the cost of fish is comparatively less. Present price of a kilogram of fish at the reservoir (wholesale price) is Rs 160.00 while a kilogram of fish used for dry fish making is only Rs 70.00 .

In addition, most of the local fish species fetch a low price due to small size and for having comparatively higher amount of bones, which make it difficult to consume, especially by children. Therefore, availability of fish for making dry fish is guaranteed and this has become popular since preparation does not involve sophisticated technology. In addition, there is an availability of a ready market and family labour.

Consumer preference for dry fish was found to be significantly high $(>85 \%)$. Results revealed that the consumers in the Minneriya area preferred dry fish to all other animal foods, mainly due to religious and cultural barriers and unavailability of other animal protein sources. In addition, one or two pieces of dry fish prepared in different ways are the appetizer for eating a plate full of rice. For a rice based diet, fish is the most supplementary and complimentary ingredient especially for the poor, since fish is rich in lysine and methionine (Edirisinghe, 1988), which are the limiting amino acids in rice.

\section{CONCLUSIONS}

The findings indicate that dry fish marketing is a profitable, low cost option for small scale producers in Minneriya. The quality of the final product could be improved by educating fishermen to use clean water and quality salt for processing. Further, the introduction of simple equipment such as solar or artificial dryers for fish drying, would help preventing unnecessary contamination. 


\section{REFERENCES}

Cutting, C.L. (1996). Fish processing and preservation. H.S.Offset Press, Daryagunj, New Delhi, pp.1-2

Edirisinghe, U. (1988). Duck - Fish Integration under Extensive Fish Culture, without the Use of a Fish Feed. pp. 292-306. In. Radhakrishna, P., Singh, M.M. \& John C.K. (ed.), World Scientific Publishing Co. Pvt. Ltd, Proc. of $2^{\text {nd }}$ Asian Conference on Technology for Rural Development, Kuala Lumpur, Malaysia.

Govindan, T.K. (1985). Fish processing technology. Oxford \& IBH publishing Co. Pvt. Ltd., 66 Tanpath, New Delhi, pp. 137-143.

Lliyasu, A.H., Onu, J.I., Midau, A. and Fintan, J.S. (2011). Economics of smoked and dried fish marketing in Yola North and South local Government areas of Adamawa State, Nigeria. J. Agric. Soc. Sci. 7, 13-16

Silva, E.I.L. and Gamlath, G.A.R.K. (2000). Catchment characteristics and water quality of three reservoirs (Victoria, Minneriya and Udawalawe) in Sri Lanka. Sri Lanka J. Aquat. Sci. $5,55-73$.

Running Title: "Salt Based Dry Fish Processing and Marketing by Fishers" 